\title{
12. Acting Women: or The Performing Self
}

\author{
She'd never make an actress though. \\ Just another pair of tights.
}

Dreiser, Sister Carrie

One practises the Theatre because one has the impression of never having been oneself, of being unable to be oneself, and of having discovered at last the means of being oneself... . From the outset of his career, the actor feels an emptiness, and lives on it.' This reflection by the French actor, Louis Jouvet, on the art he practised with such distinction over four decades, cuts both ways. On the one hand, it appears to celebrate variety and plenitude (as John Stokes points out, the 'signs of the theatrical performer are volatile... if only because they are signs of multiple identity - famous performers, "stars", may even achieve that complex totality of the image that semioticians call "structural polysemy"), ${ }^{2}$ on the other, it suggests a lack and hence the need for compensation (thus George Moore, in his diatribe upon 'Mummer Worship', who regarded the stage as 'a profession for the restless, the frankly vicious - for those who [seek] any escape from the platitude of their personality'). ${ }^{3}$

Either way, however, it implies that the performer is a kind of tabula rasa, someone who is at the very least characterized by a conspicuous lack of character, and who therefore becomes (or so the argument not infrequently continues) the imitator of other people's feelings while possessing none of their own. Indeed, both in anecdotes about actors and in the serious analysis of their art the suggestion that they prey upon life, drawing nourishment, vampire-like, from their own and other people's lives is almost a commonplace. One of the most widely quoted instances of this kind describes the eminent French actor, Talma, on hearing of the death of his father. According to C. -B. Coquelin, who recounts the event in his L'Art et le comédien (Art and the Actor, 1880), '[Talma] uttered a piercing cry, so piercing, so heartfelt that the artist always on the alert in the man instantly took note of it and decided to make use of it upon the stage later on'. ${ }^{4}$ Similarly, the popular French writer Ernest Legouvé, who in 1849 collaborated with Scribe in providing the great tragedienne Rachel with one of her most effective contemporary roles as her eighteenth-century 
predecessor at the Comédie-Française, Adrienne Lecouvreur, recalls how, on her deathbed, Rachel remained alert to the theatrical possibilities even of so extreme a moment: 'Her terrible sufferings now and then became plastically manifest in attitudes replete with statuesque and noble grace, attitudes of which she was perfectly conscious, for your great dramatic artist never forgets his ego even amidst the most cruel bodily and mental suffering. He is actor and spectator in one. However real his despair, he watches the rendering of it, ${ }^{5}$ a point that is endorsed by Janet Achurch who, fresh from her performance as Nora in A Doll's House, was reported by William Archer in Masks or Faces? as saying: 'It is impossible for me to help it. Everything that comes, or ever has come, into my own life, or under my observation, I find myself utilizing, and in scenes of real personal suffering I have had an under-consciousness of taking mental notes all the time. It is not a pleasant feeling. ${ }^{6}$

Masks or Faces?, the study in the psychology of acting which Archer wrote in 1888 with the assistance of a questionnaire that he had previously circulated among a number of well-known actors and actresses, was partly intended as a riposte to the theories advanced in one of the most famous of all discussions of the actor's art, Le Paradoxe sur le comédien (The Paradox of Acting) of 1773, in which Diderot mounts an eloquent defence of precisely the kind of behaviour that evidently disturbed even an experienced actress like Janet Achurch. Unlike his celebrated contemporary Rousseau, who had inveighed against the art of the actor in his recent Lettre à d'Alembert sur les spectacles (Letter to d'Alembert Concerning Spectacles) on the grounds that to counterfeit, be inconstant, and prey upon other people's experience was immoral and deeply corrupting, Diderot regarded the variousness of the histrionic personality, with its ability, like Proteus, to assume a multiplicity of guises, in a wholly positive light: for him 'the great actor is everything and nothing.' Just as Keats maintained that 'the poetic character has no self... Not one word I ever utter can be taken for granted as an opinion growing out of my identical nature, ${ }^{8}$ so Diderot questioned the argument 'that actors have no character because playing them all makes them lose the one that nature gave them, and that they become false, just as doctors, surgeons and butchers grow hard. I think people have taken the cause for the effect, and that they're only fitted to play all characters because they haven't one of their own' (or 'they are fit to play all characters because they have none').?

Moreover, whereas for Rousseau all behaviour, both on and off stage, was false unless predicated upon an identity of feeling and action, for Diderot the suggestion that a great actor like Garrick was somehow beside or other than himself in each of his various incarnations was a sign of health rather than immorality: wholly to identify with (say) Lear or Oedipus and lose all consciousness of the audience before whom one is performing means ceasing 
to be an actor and becoming a madman - or even worse, a bad actor. 'Extremes of feeling make for indifferent actors,' Diderot's First Speaker observes, 'an average amount of feeling gives you the mass of bad actors; a complete absence of feeling is what is needed for a great actor, ${ }^{10}$ and the paradox of great acting consequently resides in an actor's ability to move the spectator and yet retain possession of himself, to assume the role and yet always to judge the effects that his acting will produce, to continue to hear and see himself as he performs on stage, whatever the strength of the emotion he is portraying.

The periodic importance of Diderot's Paradoxe sur le comédien in subsequent discussions of acting is as illuminating about the status of the actor at the time it is invoked as it is about Diderot's original concerns. It is not difficult, for example, to perceive the attraction that Diderot's account of the self-conscious actor would hold for Brecht when he came to theorize his break with the kind of illusionistic theatre espoused by Archer, and there were certainly a number of reasons why it should have been topical during the 1880s in both France and England, where it appeared in translation in 1883, with a preface by Henry Irving. ${ }^{11}$ Among the more obvious was the visit of the Comédie-Française to London in 1879, which led to frequent contrasts being drawn between French and English acting styles (the one the result of training and intelligence, the other instinctive and emotional). But actors and acting were in any case general topics of current interest given, on the one hand, especially in England, the social movement during the latter half of the nineteenth century which saw the admission of actors and actresses to good society (Henry Irving,s knighthood in 1895 is, of course, emblematic of this) and, on the other, especially in France, the proliferating commercialization of the theatre, which predicated the marketing of a performers image in plays that served as vehicles for displaying his or her personal magnetism, whereby the performer (for example, Sarah Bernhardt) becomes a producer who is his - or generally her - own production.

This last phrase comes from The Tragic Muse, Henry James's unjustly neglected novel of artist life from 1890, in which a contrast is drawn between Paris and the values of art on the one hand, and London and their absence in politics and commerce on the other. Although James is ultimately concerned with questions of representation in general, as they apply to literature and painting as well as the theatre, the issue is rendered all the more acute here because the tragic muse of his novel is the actress Miriam Rooth, and hence an artist who is her own material. For as Coquelin had stressed, again in Art and the Actor: 'The instrument of the actor is himself. The matter of his art, that which he has to work upon and mould for the creation of his idea, is his own face, his own body, his own life, ${ }^{12}$ a fact which, at least in the illusionist tradition of the Western theatre, only serves to point up the issue of how questionable any feeling is at the moment of its theatrical representation. As 
an actress, Miriam's integrity is measured in her seeming to feel what she says when she is speaking words produced by someone else, and as she is told, by one of her admirers: 'What's rare in you is that you have - as I suspect, at least - no nature of your own... Your feigning may be honest, in the sense that your only feeling is your feigned one.'.13

The issue is again the one raised by the Paradoxe sur le comédien, but The Tragic Muse approaches it in a context that is shaped by a number of other theatre novels (most immediately, Edmond de Goncourt's anatomy of an actress, La Faustin (1887), Arsène Houssaye's La Comédienne (1884), Zola's Nana (1880), and Mrs Humphrey Ward's Miss Bretherton (1885), based on the career of the American actress, Mary Anderson), all of which are symptomatic of their time. Although finely and individually drawn by James, Miriam is therefore in some respects a representative figure. For example, like Rachel, the common ancestress of many of these nineteenth-century actress portraits, she is Jewish, and consequently perceived as racially marginal, equivocal, and naturally histrionic (a similar link is made in Daniel Deronda as well as in Arthur Symon's short fiction 'Esther Kahn' and Oscar Wilde's The Portrait of Dorian Gray, but the identification drew contemporary sanction from Sarah Bernhardt, who had just stood model for Félicien Champsaur's novel, Dinah Samuel). More particularly, Miriam is also depicted as a protean figure in continual flux, at home nowhere and everywhere, cosmopolitan but impoverished and unschooled ('ignorant, illiterate, Rachel', runs one of James's notes), ${ }^{14}$ the possessor, like Wedekind's Lulu, of whom she is the unexpected relative, of several names as well as the obligatory sphinx-like air of the finde-siècle, in short, an attractive chameleon who bears only the countenance of the occasion, as a sequence of representative movements in which she takes on the appearance, voice and gestures of whoever she happens to be with, and yet who embodies (if that isn't a contradiction in terms) the prevailing view of the actress as someone who is essentially devoid of personality, a void or 'vacancy', whose very variety is symptomatic of her lack of substance. 'I don't know what's in her,' remarks her early mentor, a diplomat called Sherringham, 'nothing, it would seem, from her persistent vacancy,', and again: 'The expression that came nearest to belonging to her... was the one that came nearest to being a blank - an air of inanity when she forgot herself, watching something.' ${ }^{16}$

In short, performers like Miriam are nothing in themselves, but merely who or what they pretend to be, a conclusion which the ultimately irremediably bourgeois Sherringham clearly finds disturbing:

It came over him suddenly that so far from there being any question of her having the histrionic nature, she simply had it in such perfection that she was always acting; that her existence was a series of parts assumed for the moment, each changed for the next, before the perpetual mirror 
of some curiosity or admiration or wonder - some spectatorship that she perceived or imagined in the people about her.... It struck him abruptly that a woman whose only being was to 'make believe', to make believe that she had any and every being that you liked, that would serve a purpose, produce a certain effect, and whose identity resided in the continuity of her personations, so that she had no moral privacy, as he phrased it to himself, but lived in a high wind of exhibition, of figuration - such a woman was a kind of monster, in whom of necessity there would be nothing to like, because there would be nothing to take hold of. ${ }^{17}$

So extended a quotation is justified because James's analysis of Miriam Rooth serves to raise a number of related issues which transcend the more or less parochial debate concerning the state of the British theatre in the 1880s. They include what Jonas Barish's excellent book of that name has defined as 'the antitheatrical prejudice, ${ }^{18}$ the on and off stage representation of women, and what might be called the psychopathology of the late nineteenth century in general, all of which emerge with particular force at this juncture because they are foregrounded by the kind of deconstruction of the idea of a single indivisible self currently being undertaken by James's close contemporaries Nietzsche and Strindberg, and which is subsequently developed from Ibsen by Freud. Indeed, James's revelation of the multiplicity and variety of the performing self in The Tragic Muse is as much a part of this wider European dimension as it is of any short-winded Anglo-Saxon great tradition, and demands consideration in relation to (for example) Strindberg's account of the modern self in the preface to Miss Julie as the 'split and vacillating' formation of an 'hysterical age' which is patched together out of 'agglomerations of past and present cultures, scraps from books and newspapers, fragments of humanity, torn shreds of once-fine clothing that has become rags' [SV 27, 104-5], or to an admittedly minor anecdote like his story 'Jubal utan jag' (Jubal without a Self), in which the account of a singer who plays so many roles that he ultimately forgets who he is, is based in part on Strindberg's one-time friend, the opera singer Algot Lange, and partly on Johan Ludvig Heiberg's portrait of the actor in 'En Sjæl efter Døden' (A Soul After Death), who had prayed to so many gods during his stage career that when dying he no longer knew on whom to call, and could not recite the Lord's Prayer without the assistance of the prompter [SS 37, 93-101]. But in such texts the multiplicity and variety of the performing self not only suggests the discontinuity of consciousness and the mobility of identity in general; it also invokes the historical moment. In what came increasingly to be regarded as the arena of urban display and city facades in which everyone was conscious of acting a role (restricting discussion to novels that concern themselves with the theatre, both Zola's vision of Paris in Nana and Herman Bang's portrait of Copenhagen in Stuk (Stucco) are relevant here), the actor by profession seemed 
to exemplify the urgent problem of how to appraise the authenticity of anyone's behaviour when everyone may be other than he or she appears, whose self in the constantly changing incarnations that he or she adopts can never be known, and for whom inconsistency and a lack of fixity in relationships and character may quite possibly be a sign of health rather than a lack of moral fibre.

I say actor, but in most contemporary discussions of the theatre, and almost without fail in the novels with which The Tragic Muse is linked, the focus of attention is upon the actress. On one level, this reflects the fact that during the nineteenth century it was the principal actress who became major box-office while male performers, with a very few exceptions such as Irving and Salvini, took second place. The international theatrical icons of the time, for example, are Bernhardt, Duse and Réjane, who succeed Rachel and the Italian actress, Adelaide Ristori. However, on another level, the idea of the actress was associated with the prevailing view of woman. Woman was seen precisely to represent the notion of the performing self, or Strindberg's 'characterless character': she was by nature - or so the doxa ran - multiple, duplicitous, unstable, and constantly changing (her mind or her hats); she was consistent only in her inconsistency, and remained, with her Gioconda smile and the obsession that she supposedly shares with the actress for gazing at herself in the mirror, an enigma or a sphinx. Or as Nietzsche, who habitually turns nineteenth-century prejudice into pseudo profundity, observes, in Human, All Too Human, multiplicity might be equated with absence, or the emptiness that Sherringham had identified in Miriam, and as such women are necessarily theatrical: 'There are women who, however you may search them, prove to have no content but are purely masks. The man who associates with such almost spectral, necessarily unsatisfied beings is to be commiserated with, yet it is precisely they who are able to arouse the desire of the man most strongly: he seeks for her soul - and goes on seeking. ${ }^{19}$ Indeed, for Nietzsche, woman epitomizes the pretence of essence. With her mimic gifts, deception, dissimulation and the donning of masks are 'natural' to her, until he depicts her 'essence' as subsumed by the multiplicity of masks she wears, precisely as the actor's is.

The actress had often been defined in terms of her power of metamorphosis and her lack of character before, of course. In Wilhelm Meisters Lehrjahre (Wilhelm Meister's Apprenticeship, 1795-96), for example, Goethe had portrayed Philina as an irresponsible, prodigal, giddy, inconstant personality, whose ability as a dancer and an actress sprang from a seemingly boundless but superficial capacity for mutability and imitation, thus provoking the now familiar comment: 'Character... and do you think such a woman has a character?' ${ }^{20}$ Indeed, it is the sense of these same qualities in Miriam that so offends Sherringham's sensibility; the histrionic conscience, as he 
defines it, 'unscrupulous, nervous, capricious, wanton', ${ }^{21}$ is 'necessarily... vulgar', ${ }^{22}$ and he can ultimately draw no real distinction between the serious actress and any other female performer: her face, he observes, 'was an elastic substance, an element of gutta-percha, like the flexibility of the gymnast, the lady who, at a music-hall, is shot from the mouth of a cannon... he had always looked more poetically, somehow, at that priestess of art. But what was she, the priestess, when one came to think of it, but a female gymnast, a mountebank at higher wages'. ${ }^{23}$

However, in the past such public women, with all the overtones that phrase conveys, had generally been drawn in explicit contradistinction to the private woman. Indeed, in taking exception here to female rather than male display, Sherringham is wholly representative. As Tracy Davis points out, in her welldocumented study of 'Actresses and Prostitutes in Victorian London', 'Female performers (regarded as a single class by the dominant culture) received the stigma [attached to displaying themselves in public] uniformly in spite of their professional specialities and socioeconomic diversity. ${ }^{24}$ Like the whore, the actress was an object of desire, whose company was purchased through commercial exchange by customers who 'tacitly agreed to suspend disbelief while a particular desire was gratified.' And as Davis adds, 'in both contexts, the vehicles of gratification were women whose identity, sincerity, and appearance were illusory but whose success relies on not giving away the hoaxes of the consumer's control of full reciprocity or enjoyment.' ${ }^{25}$

For the conspicuousness of the actress at work and, when famous, at home contravened the bourgeois separation of public and private spheres: whether a serious performer or a shameless cabotine, the behaviour of the professional actress was incompatible with a woman's properly gendered upbringing. As Rachel Brownstein argues, in her study of Rachel's impact on Charlotte Brontë (the latter, who portrayed Rachel as Vashti in Villette, saw her as a force of nature, with 'the feelings and fury of a fiend'), ${ }^{26}$ the private woman has a singular, permanent identity. She does not display herself and belongs to the family, not the crowd. Her life is private and her sexuality concealed. 'Above all she does not act,' Brownstein observes, 'a lady is served. And of course she does not, as the psychoanalysts say, "act out"; instead, literally, she suffers in. The power she may have over others arises not from anything she does but from what she consistently is: unlike the actress, she does not change. ${ }^{27}$ Moreover, whereas the actress is widely depicted as essentially cold, the parasitical and unfeeling purveyor of fake emotions, her customary foil, the faithful wife, is portrayed as consistently her warm, sincere, and modest self, wholly unable to dissemble or feign. ${ }^{28}$

Now, as A.B. Walkley remarked, in his essay on 'The Histrionic Temperament' of 1892, 'deep down in the hearts of most men there persists 
the feeling that to make a public show of yourself for money, to be always expressing ideas not your own, and emotion which you do not feel, to pretend in short to be what you are not - to clap a hump on your back and call yourself Richard the Third, as Johnson put it - is to violate the dignity of a citizen and a free man, to resign the "captaincy of your soul"' ${ }^{29}$ But what made the issue so pertinent to Walkley's contemporaries, as they passed the figure of the actress in review during the late nineteenth century, is that to the otherwise quite various masculine gaze of (for example) James and Zola, Wilde or Symons, and the Goncourt brothers or Havelock Ellis, the female stage performer was seen as identical with women generally: in short, all women were actresses by nature.

As a specimen of its kind, here is Symons in 'Extracts from the Journal of Henry Luxulyan', from the same collection that includes his actress fiction 'Esther Kahn':

What a thing it is to be a woman, and how perplexing are even their virtues! They are not made, as we are, all of a piece; they are not made to be consistent; they think so little of what we think so much of; even sex is a light, simple, and natural thing to them, to which they attach none of our morbid valuations... Think of the daily habits of their life: how many times a day they dress and undress themselves, and all it means. With each new gown a woman puts on a new self, made to match it. All day long they are playing the comedian, while we do but sit in the stalls, listen, watch and applaud. At least the play is for our entertainment: we pay them to act it: let us be indulgent if the acting is not always to our taste. ${ }^{30}$

The same argument was put, as usual more succinctly, by Nietzsche, in The Gay Science of 1881, where he likewise universalized women even as he suggested the necessity of their mendacious behaviour: 'Reflect on the whole history of women: do they not have to be first of all and above all else actresses?... love them - let your self be "hypnotized by them"! What is always the end result? That they "put on something" even when they take off everything. ${ }^{31}$ Indeed, in those discourses in which the nineteenth century liked to explore the 'natural' differences between men and women, for example, in Darwin's The Descent of Man, the former were judged as superior to women in courage, energy, intellect and inventive genius while women had the edge in terms of intuition, perception and imitation, although it is true that those faculties were also 'characteristic of the lower races, and therefore of a past and lower state of civilization, ${ }^{32}$ as well as of children, thus rendering her both phyloand ontogenetically retarded. Havelock Ellis, meanwhile, in his widely read study Man and Woman, noticed 'an interesting parallelism, and probably a real deep-lying nervous connection, between the suggestibility of women and the special liability of female butterflies, birds, and mammals to be mimetic 
in coloration, ${ }^{33}$ which led him to argue that women naturally excelled in 'at least one art... the art of acting' since, among other things, 'the circumstances of women's social life have usually favoured a high degree of flexibility and adaptability as regards behaviour; and they are, again, more trained in the vocal expression both of those emotions which they feel and those emotions which it is considered their duty to feel. ${ }^{34}$

In support of his argument Ellis quotes Rachel's colleague Legouvé on the mobile, ardent, and varied impressionability that acting requires, and which consequently makes 'the dramatic faculty... more native to women than to men'. ${ }^{35}$ He might equally well have quoted the very incarnation of contemporary theatricality, Sarah Bernhardt, whose book, L'Art du théatre, declared that acting 'contains in itself all the artifices which belong to the province of woman: the desire to please, the facility to express emotions and hide defects, and the faculty of assimilation which is the real essence of woman $^{\prime 36}$ (although had he done so, he would doubtless not have noticed, as Elaine Aston does, in her recent monograph on Bernhardt, that if the language of the theatre is indeed a female language, acting for Bernhardt 'was no longer simply a question of parading as a desirable love-object, but rather a baring of the female psyche - the inner female life made visible through its language of body, face and voice'). ${ }^{37}$

But so subtle a reading of the actress, who emerges as both an image of woman and a woman composed of images, cannot conceal the dangers inherent in this nineteenth-century view of acting women, for whom role-play is frequently linked with the notion of foreplay and subsequent prostitution. Like the prostitute, the actress was engaged in what Sherringham called 'nightwork', ${ }^{38}$ and she was likewise easily seen as abandoning her body to the multitude, since her body was the instrument through which her art gave pleasure. For as Barish observes, 'when we alter or diversify for pleasure, when the body is made the instrument of that pleasure, when the pleasure is available to anyone who can pay for it...the activity turns into a form of metaphysical prostitution for which no loathing can be too strong and no repudiation too absolute, ${ }^{39}$ and to the nineteenth-century imagination this image of the actress effortlessly shedding or assuming names and identities, and displaying - like Wedekind's Lulu - an obliging adaptiveness to the whims of her male customers, amongst whom she circulates as a commodity within the capitalist economy of male desire, was both attractive and repellent. In so far as they did not signify the sexual body so much as its production as an elaborate spectacle, a commodified image, both prostitute and actress could be seen as offering themselves promiscuously to the passer-by, and they likewise shared not only their working hours and a lack of personal identity which, in the light of Diderot's paradox, might manifest itself most acutely when each absented themselves from authentic feeling at the 
moment of greatest passion, but also the possibility of a rare social mobility and a concern with costume and make-up in a flickering, gas-lit world where both solicited the attention of the concupiscent male gaze. ${ }^{40}$ Indeed, the intoxicating realm of the theatre, which included an actress's training, her costume and its fitting, make-up, green rooms, dressing rooms and stage-doors, housed a complex sexual system, and released a powerful erotic charge, as is indicated by the Goncourts' description of a first night at the Cirque:

The balcony was resplendent with demi-mondaines and the corridors were crowded with those handsome men wearing foreign decorations who fill the corridors of the Opera on ball nights. In the boxes there was quite a pretty array of prostitutes. It is wonderful what a centre of debauchery the theatre is. From the stage to the auditorium, from the wings to the stage, from the auditorium to the stage and from one side of the auditorium to the other, invisible threads criss-cross between dancers' legs, actresses' smiles and spectators' opera glasses, presenting an overall picture of Pleasure, Orgy, and Intrigue. It would be impossible to gather together in a smaller space a greater number of sexual stimulants, of invitation to copulation. It is like a Stock Exchange dealing in women's nights. ${ }^{41}$

The same might also have been said (indeed, it often was) about any of the other available theatrical venues - whether for ballet, opera, music-hall, masked ball, circus, or the café concert, with its corbeille of young women sitting in silent display behind the singer - and when, in Nana, Zola has his theatrical manager, Bordenave, describe the theatre at which Nana makes her debut as 'mon bordel' (my brothel), this was as much a commonplace as forthright naturalism. The Goncourts, for example, record M. Hiltbrunner, the manager of the Théâtre des Délassements, telling the architect Cabouillet, 'Monsieur, my theatre is a brothel', ${ }^{42}$ and Zola in fact modelled his theatre on the Variétés, where the first half-dozen rows were always reserved for male spectators seeking post-performance pleasures.

It is, however, the frequent identification of the prostitute as someone who moves easily between roles in a play of intriguing signs and changing masks that marks perhaps the most significant point of identification with the actress, and consequently with the conception of the performing woman that I have been tracing here. ${ }^{43}$ One way forward would therefore be to examine the numerous plays in which actresses were required to perform the role of actress on stage. Modestly conceived in Britain, and concerned more with manners and morals than art, such roles were generally deployed to confirm the prevailing social order. Thus, in Robertson's Caste (1867), where a dancer marries into the aristocracy and leaves the stage, it is her experience as a performer that helps her adapt to the milieu in which she now finds herself. In Pinero's Trelawny of the 
Wells (1898), meanwhile, the brief experience (lasting all of one month!) that the actress Rose enjoys in a genuine upper-class milieu renders her incapable of playing her old parts successfully when she returns to the stage. She has been touched by true refinement, and can no longer dissemble: 'I was nothing but an actress,' she laments, 'We are only dolls, partly human, with mechanical limbs that will fall into stagey postures, and heads stuffed with sayings out of rubbishy plays... It isn't the world we live in, merely $a$ world - such a queer little one! I was less than a month in Cavendish Square, and very few people came there: but they were real people - real! ${ }^{\text {44 }}$

After such an effusion, a comparison with the less inhibited theatrical portraits of the actress in France and Germany comes as some relief. Whereas the moral of mid-century plays like Meilhac and Halévy's ubiquitous Frou-Frou (1869) implicitly echoed Wilkie Collins's No Name (1862) - or indeed Mansfield Parkin suggesting that an ability to transform oneself into someone else was morally dangerous, and that true innocence could therefore be measured in terms of a character's lack of ability as a performer, by the end of the century the actress was frequently being celebrated in all her 'infinite variety'. This is the case with Meilhac's Ma Cousine (1890) and Berton and Simon's Zaza (1898), both of which were devised as vehicles for Gabrielle Réjane. At one point in the latter, Réjane is in fact discovered in precisely the kind of milieu that had made Flaubert's nostrils flare, namely an actress's loge at a café concert in Saint-Etienne, performing the role of an actress performing her toilette, dressing, making-up, unpinning her false hair, and dabbing her shoulders with a powder puff, ${ }^{45}$ a scene that is almost contemporary with the extraordinary third act of Wedekind's Erdgeist (Earth Spirit, 1895), in which Lulu is shown backstage, changing her costumes under the gaze of her mentor, Dr Schön, as Wedekind explores both the ambiguities of theatrical representation in general, through the suggestive parallel between the on-stage actress, who is pretending to be an actress, and her off-stage existence, and the more general predicament of a woman who has been allotted her role by a male creator, who is motivated at least in part by his sexual fantasies. ${ }^{46}$ And this in turn recalls one of the most enduring plays of the later nineteenth century, namely $A$ Doll's House (1879), in which Ibsen effectively subverts the prevailing notion of woman as a player of roles. Through his portrait of Nora Helmer being rehearsed by her husband in the roles that he has sought to inculcate in her, one may see both the process by which she has been constructed as a woman to serve the male interests of contemporary society and the way in which, in the final act, she takes off the fancy-dress costume in which he has attired her, and dons her own clothes, in order to seek her own life as herself.

It is intriguing, and surely no coincidence, that the scene in which her husband's dressage reaches its climax should be the hysterical tarantella, brought back by the Helmers from Capri, which Nora dances at the close 
of Act Two. ${ }^{47}$ As Catherine Clément and Hélène Cixous point out, in their revealing study of La Jeune née (The Newly Born Woman), ${ }^{48}$ the Southern Italian woman's dance of the tarantella includes, among other movements, the classic arc of the hysteric as defined in the manuals of late nineteenth-century French psychology, and the hysteric (as Freud and Breuer would shortly suggest, in their Studies on Hysteria of 1895) transforms her body into a kind of theatre where she replays scenes from the past that she cannot otherwise express, just as Nora dances what she cannot say. In fact, at the close of a century in which the male imagination displayed a febrile obsession with the figure of Salome, a delight in dancing was frequently regarded as typical of female neurasthenia, ${ }^{49}$ and any such link between dancing, women, roleplaying and hysteria ought therefore to alert us to the possibility of a further resonance in the nineteenthcentury notion of acting women. For if the model of fashionable womanhood during the 1850s and 1860s was the grande cocotte, or courtesan, many of whom, like Thérèse Lachmann, Cora Pearl or Lola Montez, used the theatre as a means of staging their beauty, for the fin-de-siècle she was supplanted by the hysteric. Indeed, again and again in contemporary accounts of prominent actresses from this period, it is their kinship with the hysteric that is stressed. Gilles de la Tourette, for example, the author of a Traité clinique et thérapeutique de l'hystérie (Clinical and Therapeutic Treatise on Hysteria), published in Paris, in 1891, admired Aimée Desclée's assumption of the title role in Frou-Frou for being 'like a singularly precise and well observed type of worldly hysteria,' ${ }^{50}$ and as John Stokes has pointed out, Desclée's modernity was identified with neurosis in the precise, clinical meaning of the word. A.B. Walkley, meanwhile, dubbed Réjane 'the muse of hystero-epilepsy' for her ability to 'so cleverly reproduce the gradual crescendo from nervous irritation to suffocating or shrieking hysteria, ${ }^{51}$ while to Arthur Symons, as to many others, including her visual chronicler, Toulouse-Lautrec, the morbid and enigmatic Jane Avril, who had indeed spent much of her youth in clinical care for chorea, embodied the pathological choreography of the fin-de-siècle in her dancing at the Moulin Rouge..$^{52}$ Likewise, Eleonora Duse was widely praised for her ability to 'outclass everyone in her portrayal of characters with hysterical temperaments'. ${ }^{53}$ Thus Adelaide Ristori, who was otherwise often lukewarm about her younger compatriot, acknowledged Duse's achievement in creating 'for herself a sort of convention that is quite hers, through which she effectively becomes the woman of modern times, with all her complaints of hysteria, anaemia and nerve trouble, ${ }^{, 54}$ as did, in almost the same words, a female commentator in the Fortnightly Review, for whom she appeared 'In brief... the modern actress, the fin de siècle woman par excellence, with her hysterical maladies, her neurotism, her anaemia and all its consequences. ${ }^{55}$ Hugo von Hofmannsthal, meanwhile, also intending praise, christened her 'Our Lady of the Quivering Nerves. ${ }^{56}$ 
From this it was again only a step to seeing all women as not merely actresses but also hysterics, especially when, to many female as well as male spectators, Duse seemed to represent woman rather than a sequence of different women's roles. Thus one of Strindberg's old sparring partners, Laura Marholm, insisted that what Duse 'gave us [was] the secret, inner life of woman which no poet can wholly fathom, and which only woman herself can reveal, ${ }^{, 57}$ and Helen Zimmern maintained that 'she is before all else a woman, in every sense of the term - a woman and not an actress. ${ }^{58}$ Indeed, during the last thirty years of the nineteenth century, histrionics and hysteria were inextricably linked in the male imagination, and continued to be so well on into the present century when (for example) Fritz Wittels may be observed remarking, in a widely disseminated study of 1956 on Freud and His Time, that 'dramatic art should be the true domain of the hysteric, for she is always playing a part, never taking herself or the world seriously. ${ }^{59}$ But today the divided consciousness of the actress imitating (as Diderot suggests in his Paradoxe) the movement, actions, gestures, the entire expression of a being altogether beyond herself, someone who was either beside herself in her role or lost in her part as she mouthed a script that she had not written herself, recalls nothing so much as the celebrated Tuesday seminars and Friday spectacles that were staged regularly at the hospital of La Salpêtrière in Paris by the French neurologist Jean-Martin Charcot. Sometimes dubbed the 'Napoleon of neurosis', he and his cast of generally young and attractive female patients performed what Georges Didi-Huberman calls 'la pantomime des symptômes, ${ }^{60}$ before a predominantly male audience that frequently included eminent writers like Maupassant, Edmond de Goncourt, and Alphonse Daudet, as well as leading actors and actresses, painters, journalists and demi-mondaines. ${ }^{61}$ Charcot was in fact one of the most masterly of the many metteurs-en-scène produced by the theatrical age of the Belle-Epoque: when he lectured on tremors, for example, three or four women were introduced wearing hats with very long feathers. The trembling of the feathers allowed the audience to distinguish the specific characteristics of the tremors caused in various diseases. ${ }^{62}$ As a skilled mimic, Charcot would also imitate the gait, behaviour, and voice of a patient for his audience himself, but what particularly drew le Tout-Paris to his lectures was the dramatic presentation of the various stages of la grande hystérie itself, performed in a vast amphitheatre which contained both RobertFleury's famous painting of 1887 depicting Pine! freeing the insane following the first French Revolution, and a lithograph of Charcot himself, lecturing in the guise of a scientific Svengali on a pliable, swooning, and half-undressed young woman, to a group of admiring and attentive men. Although he helped pioneer the recognition of hysteria as a male affliction, it is significant that the photographic record of Charcot's experiments, the Iconographie de la Salpêtrière, 
does not contain a single male portrait: his stars were all women, like his prima donna, Blanche Wittmann, otherwise known as 'la reine des hystériques' for her talent at reproducing every stage of the major attack, from dancing via the epileptoid, to clowning and what was provocatively called 'attitudes passionnelles', or her fifteen-year-old co-star, Augustine, whose re-enactment of the violation that had in all likelihood precipitated her affliction made her 'un véritable prodige de plasticité, un véritable prodige de théâtralité. ${ }^{63}$ Under hypnosis, which partly secured the division of the performer into the acting and feeling being of Diderot's paradox, and with the expressivity of actresses repeating their roles beneath the insistent gaze of a répétiteur, these women acted out their identifications, adopting poses, reliving roles, and re-enacting the past, as they embodied a pre-existing and unconscious script before the eyes of a male spectator who, as in the theatre of the time, was an essential part of the performance. Consequently, it is hardly surprising to discover that a playwright, André de Lorde, should have collaborated with the clinician Alfred Binet in dramatizing Charcot's lessons at the Salpêtrière in several plays, including Une Leçon a la Salpêtrière, first performed at the Grand Guignol in $1908 .^{64}$

Even before Charcot, however, the hysteric had been perceived as essentially an actress. Thus Jules Falret, in his Folie raisonnable ou folie morale (Reasonable Madness or Moral Madness) of 1866, explained: 'These patients are real actresses; they have no greater pleasure than in deceiving the people with whom they have some relationship, ${ }^{65}$ and the remedy proposed for such 'hardened actresses' by the Victorian doctor, Thomas Clifford Allbutt, had been to empty the theatre and take away the audience by placing the patient in solitary confinement. Charcot's own records of his sessions are in fact sometimes written up in dialogue form (perhaps helping the patients, and the doctors who coached them, to perfect their roles in advance: Blanche Wittmann later confessed that, even under hypnosis, she had - like a Diderotian actress - always been conscious of her enactment), and the photographic material produced at the Salpêtrière likewise provides a veritable thesaurus of theatrical gestures, which were sometimes given titles like 'Lady Macbeth' or 'The Actress'. Indeed, as Elaine Showalter remarks, of the frequently photographed Augustine, who for her audience at least possessed the fortunate gift of being able to divide her attacks into scenes and acts with tableaux and intermissions (in fact, she appeared before the camera so often that she developed an additional hysterical symptom of seeing the world in black and white): 'All of her poses suggest the exaggerated gestures of the French classical acting style, or stills from silent movies. ${ }^{66}$

As Charles Bernheimer points out, at best 'Charcot's theater had one tremendous attraction for its equivocal stars: it afforded suffering women a 
stage on which to express their desire, in however displaced and disguised a form, ${ }^{67}$ and in this gallery of symptoms from which the patient's subtext might eventually be gleaned, there is something of the ability that Hofmannsthal noted in Duse to 'act the transitions; she fills the gaps of the motivation; she reconstructs the psychological novel in drama, ${ }^{68}$ though only, it would seem, when she had lost herself in a role and become, like the hypnotized patient, the antithesis of Diderot's always conscious actor. It is, however, as a Trilby-like somnambulist, who acts as if in a magnetic sleep, that the actress is frequently portrayed at this time, by (for example) Symons in 'Esther Kahn' or Theodore Dreiser in Sister Carrie. This is a strategy that enables the male author, like the audience at the Salpêtrière, to gratify a desire in which women are regarded as at once debased and out of control and the rewarding if dangerous stimuli to creation. In their protean mutability, the actress and hysteric are merely the avatars of all women, as is suggested by the Goncourts in their novel Germinie Lacerteux (1864), whose humble heroine is overheard in hysterical delirium to speak just like the great Rachel (which is perhaps hardly surprising since Charcot had judged Jews to be disproportionately susceptible to hysteria and mental illness generally) ${ }^{69}$ : 'her language became as unrecognizable as her voice, transposed into the tones of a dream. This soared above the woman herself, above her normal tone and expression... The phrases came from her mouth with their rhythm, their heartbreak and their tears, as from the mouth of a wonderful actress... such acting, such intonations, a voice as dramatic and as broken as this voice, like that of a consumptive spitting out her heart - she only recalled these things in Mlle Rachel. ${ }^{2}{ }^{70}$

The construction of gender entails both the product and the process of its representation, and at the end of the nineteenth century woman, in the form of the actress, appeared as the very ground of representation, a false universal constituted by the concuspicent male gaze, which located in her image the site of male desire. At times, of course, she colluded in that process. As Laura Mulvey points out, 'in their traditional exhibitionist role women are simultaneously looked at and displayed, with their appearance coded for strong visual and erotic impact so that they can be said to connote to-be-looked-at-ness, ${ }^{171}$ a moment that Wedekind captures so memorably when, in Earth Spirit, Lulu asks the painter Schwarz whether he wishes her to pose for him with her lips slightly parted..$^{72}$ In both theory and practice the most extreme incarnations of the fin-de-siècle actress portray her as a self-regarding solipsist, engaged in reinforcing the naturalized assumptions of the prevailing ideology, whether 'subtly of herself contemplative'73 like Rossetti's Lilith or Mallarmé's mirrorgazing Hérodiade, or discovered on stage, as Symons describes Maeterlinck's mistress, the actress and singer Georgette Leblanc, seemingly absorbed entirely in herself: 'When I heard her [sing],' Symons writes, 'there was a mirror on 
the other side of the room, opposite her; she saw no one else in the room, once she had surrendered herself to the possession of the song, but she was always conscious of the image of herself which came back to her out of the mirror: it was herself watching herself, in a kind of delight at the beauty which she was evoking out of the words, notes, and expressive movement. ${ }^{34}$

In this role, too, which is of course that of Walter Pater's Gioconda and her enigmatic, exclusive smile, the now almost impersonal, inactive woman once again eludes definition: like the actress Miriam Rooth with whom we started, she remains a void or vacancy. But in the new century, as Nora asserts her independence in the guise of Freud's Dora by adopting what Jacques Lacan once called 'the smile of the Mona Lisa', ${ }^{75}$ this vacancy, or seeming lack of definition that woman supposedly shares with the actress (or indeed, the actor), will assume a positive charge, as for example in Julia Kristeva's revisioning of woman, in her essay 'Woman Can Never Be Defined': 'A woman cannot "be”; it is something which does not even belong in the order of being. It follows that a feminist practice can only be negative, at odds with what already exists.... In "woman" I see something that cannot be represented, something that is not said, something above and beyond nomenclatures and ideologies. ${ }^{76}$

But no more can the actor, which partly accounts for the depth and venom of the anti-theatrical prejudice. Whatever else it may be, in the Western tradition at least acting of any worth is a celebration of variety and difference, of being other and more than one ordinarily is. Thus it retains the necessary power to disturb and change the world in which it comes to life; and although, as the great nineteenth-century Danish actress, Johanne Luise Heiberg, once remarked, 'the strange thing about such imaginative creatures... is that every footprint they make on their way through life immediately fills up again behind them, ${ }^{77}$ in this emptiness, or evanescence, remains the potent sign of an inexhaustible plenitude. ${ }^{78}$ 